\title{
Penerapan Metode Show And Tell Untuk Meningkatkan Keterampilan Berbicara Tema 7 Indahnya Keragaman Di Negeriku
}

\section{Isna Maulida Rahmayanti1*, Desak Putu Parmiti2}

${ }^{12} J u r u s a n$ Pendidikan Guru Sekolah Dasar Universitas Pendidikan Ganesha

\section{A R T I C L E I N F O}

Article history

Received January 21, 202

Revised February 03, 202

Accepted April 08, 2021

Available online May 25, 2021

Kata Kunci:

Show and tell, keterampilan

berbicara

Keywords:

Show and tell, speaking skills

\section{A B S T R A K}

Penelitian ini bertujuan untuk meningkatkan keterampilan berbicara dengan metode Show and tell pada siswa kelas IV SD Negeri 1 Pernasidi. Jenis penelitian ini adalah penelitian tindakan kelas dengan subjek penelitian adalah siswa kelas IV SD Negeri 1 Pernasidi tahun ajaran 2018/2019. Penelitian dilaksanakan dalam dua siklus, setiap siklus ditempuh dengan 2 kali tindakan dan terdiri atas 4 tahap yaitu perencanaan, pelaksanaan, observasi, dan refleksi. Data hasil penelitian diperoleh selama kegiatan pembelajaran berlangsung dengan menggunakan observasi dan dokumentasi. Penelitian ini menggunakan bentuk analisis data deskriptif. Hasil penelitian menunjukkan bahwa (1) keterampilan berbicara mulai dari siklus I ke siklus II mengalami peningkatan, (2) Ketuntasan keterampilan berbicara dengan kriteria baik pada pelaksanaan tindakan Siklus I 45\%, dan pada pelaksanaan tindakan Siklus II meningkat menjadi 75\%. Dengan demikian penerapan metode show and tell dalam pembelajaran siswa kelas IV SD Negeri 1 Pernasidi telah mencapai indikator ketercapaian keterampilan berbicara yaitu $70 \%$ dari jumlah siswa yang diteliti pada kriteria baik (76-100\%).

\section{$A B S T R A C T$}

This reseach aims to increase the speaking skills with Show and tell method grade IV of primary school of 1 Pernasidi. This type of research is Classrom Action Reasearch. This subject of this research are students grade IV of primary school of 1 Pernasidi school year 2018/2019. This research held in two cycles, in every cycle held in two actions and consists of 4 stage are plan, do, observation, and reflection. Research data obtained during the learning be held with used observation and documentation. This research used descriptive data analysis The research result showed that (1) speaking skills start cycle 1 to cyle 2 had increase, (2) completeness speaking skills with a good criteria percentage in cycle I get 45\%, in cyle II percentage increased till $75 \%$. Accordingly, Show and tell method in learning can use to increase student's speaking skills grade IV of primary school of 1 Pernasidi reached indicator of speaking skills 70\% from students with good criteria (76-100\%).

\section{Pendahuluan}

Pendidikan merupakan kegiatan belajar mengajar dimana menghasilkan perubahan perilaku dan pengembangan kemampuan diri sendiri. Dalam undang-undang No. 20 Tahun 2003 tentang Sistem Pendidikan Nasional Bab I Pasal 1 ayat 1 dijelaskan bahwa: Pendidikan merupakan usaha sadar dan terencana untuk mewujudkan suasana belajar dan proses pembelajaran, agar peserta didik secara aktif mengembangkan potensi dirinya untuk memiliki kekuatan spiritual keagamaan, pengendalian diri, kepribadian, akhlak mulia, serta keterampilan yang diperlukan dirinya, masyarakat, bangsa dan negara.

Dari undang-undang di atas, pendidikan tidak hanya bertujuan membentuk siswa yang cerdas kognitif, namun cerdas secara keterampilan dan memiliki karakter. Dalam bahasa Indonesia, kita mengenal adanya empat keterampilan dalam berbahasa. Menurut Tarigan (2008: 1), keterampilan berbahasa memiliki empat komponen, yaitu keterampilan menyimak, keterampilan berbicara, keterampilan membaca, dan keterampilan menulis. Empat keterampilan tersebut saling berkaitan dan tidak dapat dipisahkan antara yang satu dengan yang lain. Salah satu keterampilan yang harus dilatih dalam pembelajaran di sekolah dasar yaitu keterampilan berbicara. Pembelajaran keterampilan berbica perlu dikuasai untuk mengembangkan kemampuan dalam berpikir, membaca, menulis, dan menyimak (Faris dalam Supriyadi, 2005: 179).

Keberhasilan pendidikan dapat ditunjukkan dari kualitas pendidikan yang ada, dimana kualitas pendidikan itu meliputi kualitas proses maupun kualitas lulusan. Jadi pendidikan dikatakan berhasil apabila proses belajar- mengajarnya berjalan dengan baik serta menghasilkan output yang berkualitas. Di dalam peningkatan mutu pendidikan perlu efisiensi pendidikan, yang mempunyai arti bahwa 
proses pendidikan harus mencapai hasil yang maksimal dengan biaya yang wajar. Dalam pandangan yang lebih luas efisiensi pendidikan berkaitan dengan profesionalisme dan manajemen pendidikan yang di dalamnya mengandung disiplin, kesetiaan dan etos kerja. Hal ini kurang disadari oleh para penyelenggara pendidikan yang berada di daerah pada umumnya, yang pada gilirannya mengakibatkan munculnya permasalahan pada dunia pendidikan. Masalah pendidikan yang dihadapi dewasa ini yang sangat urgen adalah rendahnya mutu pendidikan pada setiap jenjang pendidikan, khususnya pada pendidikan dasar dan menengah. Berbagai usaha telah dilakukan untuk meningkatkan mutu pendidikan antara lain melalui berbagai pelatihan dan peningkatan kualitas guru, penyediaan dan perbaikan sarana prasarana pendidikan serta perbaikan kurikulum dan peningkatan mutu menajemen pendidikan sekolah. Namun demikian (Marisa, 2019).

Pembelajaran pada hakikatnya merupakan proses interaksi antara peserta didik dengan lingkungannya, sehingga terjadi perubahan perilaku kearah yang lebih baik (Mulyasa, 2010). Proses pembelajaran sepenuhnya diarahkan pada pengembangan pada ranah kognitif, afektif, dan psikomotor secara utuh/holistik. Dengan demikian proses pembelajaran secara utuh melahirkan kualitas yang mencerminkan keutuhan penguasaan sikap, pengetahuan, dan keterampilan (Depdiknas, 2013).Pencapaian tujuan pembelajaran ini dapat ditentukan oleh adanya motivasi peserta didik untuk berubah menjadi lebih baik. Berdasarkan observasi yang telah dilakukan di Prodi Pendidikan Biologi Universitas Sulawesi Barat (UNSULBAR) pada matakuliah Biokimia, diketahui bahwa motivasi dan hasil belajar kognitif mahasiswa masih rendah. Hal ini karena sebagian besar mahasiswa tidak memperhatikan penjelasan dosen pada saat mengajar sertaselalu menunda-nunda waktu saat mengumpulkan tugas. Hasil ujian Biokimia juga sangat rendah, dimana hampir $80 \%$ mahasiswa mendapat nilai di bawah 60 . Hal yang sangat disayangkan bahwa selama ini mahasiswa belum pernah melaksanakan kegiatan eksperimen sehingga belum memberdayakan keterampilan proses sains. Hal ini menyebabkan materi pembelajaran yang telah dipelajari akan cepat dilupakan oleh mahasiswa (Syamsiara Nur, 2017).

Belajar adalah proses perubahan perilaku ke arah yang lebih baik, dari tidak tahu menjadi tahu, dari tidak bisa menjadi bisa. Menurut Winkel (1997), belajar adalah semua aktivitas mental atau psikis yang berlangsung dalam interaksi aktif dalam lingkungan, yang menghasilkan perubahan-perubahan dalam pengelolaan pemahaman. Menurut Ernest R. Hilgard dalam (Sumardi Suryabrata, 1984) belajar merupakan proses perbuatan yang dilakukan dengan sengaja, yang kemudian menimbulkan perubahan, yang keadaannya berbeda dari perubahan yang ditimbulkan oleh lainnya. Sifat perubahannya relatif permanen, tidak akan kembali kepada keadaan semula. Tidak bisa diterapkan pada perubahan akibat situasi sesaat, seperti perubahan akibat kelelahan, sakit, mabuk, dan sebagainya (Marisa, 2019).

Belajar juga merupakan suatu perubahan dalam tingkah laku menuju perubahan tingkah laku yang baik, dimana perubahan tersebut terjadi melalui latihan atau pengalaman. Perubahan tingkah laku tersebut harus relatif mantap yang merupakan akhir daripada suatu periode waktu yang cukup panjang. Tingkah laku yang mengalami perubahan karena belajar tersebut menyangkut berbagai aspek kepribadian baik fisik maupun psikis, seperti perubahan dalam pengertian, pemecahan suatu masalah/berfikir, keterampilan, kecakapan ataupun sikap (Nidawati, 2013).

Keterampilan berbicara berperan penting dalam menghadapi kehidupan masyarakat yang demokratis. Siswa diberikan bekal berupa keterampilan berbicara diharapkan siswa dapat menjadi generasi muda yang demokratis, kritis, dan berkarakter. Namun di lapangan didapati keterampilan berbicara siswa masih belum optimal.

Dari pengamatan, siswa kelas IV di SD Negeri 1 Pernasidi secara umum jika diminta menceritakan sesuatu siswa terlihat tidak percaya diri. Siswa akan malu-malu dalam bercerita, terkadang tidak lancar, dan menjadikan cerita yang disampaikan tidak jelas. Oleh sebab itu, pembelajaran yang meningkatkan keterampilan berbicara perlu ditingkatkan. Demi tercapainya tujuan tersebut secara efektif, diperlukan suatu metode yang tepat dalam pelaksanaannya. Menurut Cahyani (2012: 95), terdapat beberapa model yang dapat diterapkan dalam pengajaran berbicara diantaranya sebagai berikut: Ulang-ucap; Lihatucapkan; Memerikan; Menjawab pertanyaan; Bertanya; Pertanyaan menggali; Melanjutkan; Menceritakan kembali; Percakapan; Parafrase; Reka cerita gambar; Bermain peran; Wawancara; serta Memperlihatkan dan bercerita (Show and Tell). Pada penelitian ini, peneliti mencoba menerapkan Show and Tell. Metode Show and Tell memberikan kesempatan untuk mengembangkan bahasa ekspresif anak melalui belajar membuat dan membangun bahasa (Dailey, 1997). Dengan metode Show and Tell, diharapkan dapat merangsang dan menambah kosakata serta dapat menstimulasi kemampuan berbicara pada siswa.

Rumusan masalah yang akan diteliti oleh penulis adalah "apakah keterampilan berbicara Tema 7 Indahnya Keragaman Di Negeriku pada siswa kelas IV SD Negeri 1 Pernasidi meningkat setelah diterapkannya metode Show and Tell?". Tujuan Penelitian secara umum bertujuan untuk mengetahui peningkatan keterampilan berbicara setelah diterapkannya metode Show and tell pada siswa kelas IV SD 
Negeri 1 Pernasidi. Dalam penelitian ini dibatasi hanya memecahkan masalah rendahnya keterampilan berbicara pada siswa kelas IV tema Indahnya Keragaman di Negeriku SD Negeri 1 Pernasidi tahun pelajaran 2018/2019.

\section{Metode}

Penelitian ini merupakan penelitian tindakan kelas (Classroom Action Research) yang dilaksanakan dalam dua siklus, dengan tiap siklusnya terdiri dari perencanaan, pelaksanaan, observasi, dan refleksi. Rancangan yang dimaksud adalah tindakan berupa penerapan metode Show and Tell. Subjek penelitian ini adalah siswa kelas IV SD Negeri 1 Pernasidi tahun pelakajaran 2018/2019, Banyumas, Jawa Tengah yang berjumlah 20 siswa. Objek penelitian ini adalah keterampilan berbicara tema Indahnya Keragaman di Negeriku. Metode pengumpulan data yang digunakan adalah dengan observasi dan dokumentasi. Data mengenai keterampilan berbicara diperoleh dengan lembar observasi keterampilan berbicara yang dilaksanakan setiap pertemuan.

Analisis data yang digunakan yaitu analisis deskriptif secara presentase terhadap data yang diperoleh dari hasil observasi keterampilan berbicara yang terdiri dari aspek kebahasaan (pengucapan, pengembangan kosa kata, dan pembentukan kalimat) serta aspek non kebahasaan (keberanian, kelancaran, dan ekspresi). Kriteria keberhasilan dalam penelitian ini adalah $70 \%$ dari jumlah siswa mendapatkan nilai dengan kriteria baik (76-100\%). Indikator keberhasilan dalam penelitian ini adalah adanya peningkatan keterampilan berbicara melalui model Show and Tell. Peningkatan keterampilan dapat dilihat dari peningkatan rata-rata persentase setiap aspek keterampilan yang dikembangkan, yaitu apabila 70\% dari jumlah siswa mencapai indikator dalam persentase baik (76\%-100\%).

\section{Hasil Dan Pembahasan}

Data yang diperoleh dalam penelitian ini adalah keterampilan berbicara siswa. Keterampilan berbicara diukur menggunakan observasi keterampilan berbicara yang dilakukan setiap pertemuan.

\section{Hasil Tindakan Siklus I}

Peneliti membuat rencana pelaksanaan pembelajaran (RPP) yang didesain menggunakan model Show and tell. Instrumen yang digunakan sebagai alat penilaian yaitu lembar observasi keterampilan berbicara.

Kegiatan pembelajaran diterapkan pada siswa kelas IV SD Negeri 1 Pernasidi dan berjalan sesuai dengan apa yang telah direncanakan peneliti dalam RPP. Data yang diperoleh, siswa dengan keterampilan berbicara kriteria baik $45 \%$.

\section{Refleksi Siklus I}

Dari hasil siklus I dapat diketahui bahwa secara umum keterampilan berbicara siswa kelas IV SD Negeri 1 Pernasidi belum mencapai hasil yang maksimal. Hal ini disebabkan karena keterampilan berbicara siswa yang masuk dalam kriteria baik belum mencapai 70\% dari jumlah seluruh siswa sehingga perlu dilaksanakan tindakan pada Siklus II. Permasalahanyang muncul selama siklus I yaitu pengondisian kelas yang kurang efektif. Proses pembelajaran diperbaiki dengan cara memberikan reward bagi siswa yang tertib selama siswa lain bercerita.

\section{Hasil Tindakan Siklus II}

Berdasarkan hasil refleksi siklus I maka dilakukan perencanaan tindakan pada siklus II. Peneliti membuat rencana pelaksanaan pembelajaran (RPP) yang didesain menggunakan model Show and tell. Kegiatan pembelajaran diterapkan pada siswa kelas IV SD Negeri 1 Pernasidi dan berjalan sesuai dengan apa yang telah direncanakan peneliti dalam RPP. Data yang diperoleh, siswa dengan keterampilan berbicara kriteria baik $75 \%$.

Dari hasil siklus II diketahui bahwa keterampilan bicara siswa sudah mencapai indikator keberhasilan yaitu 70\% kriteria baik dari siswa yang diteliti.

Sehingga dapat disimpulkan bahwa pembelajaran Tema Indahnya Keragaman di Negeriku dengan menerapkan metode Show and tell telah berhasil. Pembelajaran dengan menerapkan metode Show and tell terjadi peningkatan hasil dari siklus I sampai siklus II. Keterampilan berbicara siswa Siklus I dan Siklus II dapat dilihat pada diagram berikut. 


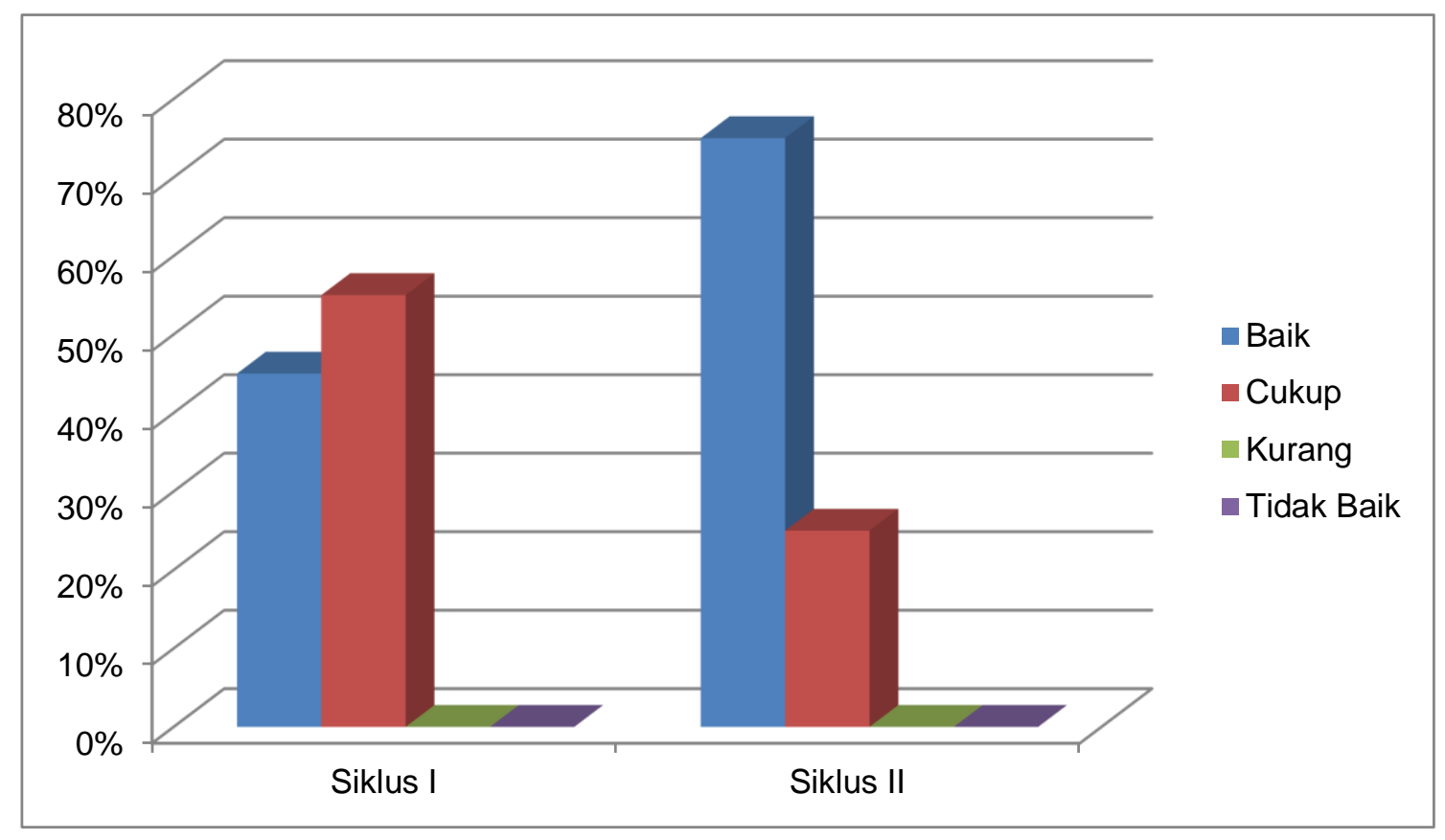

Gambar 1. Grafik Persentase Peningkatan Keterampilan Berbicara Siswa Siklus I dan Siklus II.

Penggunaan metode Show and tell dapat meningkatkan keterampilan berbicara siswa kelas IV Tema Indahnya Keragaman di Negeriku. Hal ini dapat dilihat siklus I presentase siswa dengan keterampilan berbicara kriteria baik mencapai $45 \%$ dan pada siklus II presentase keterampilan berbicara siswa $75 \%$. Dengan demikian, presentase tersebut memenuhi indikator keberhasilan yaiu $70 \%$ kriteria baik dari siswa yang diteliti.

Berdasarkan hasil observasi pada pelaksanaan pembelajaran melalui metode show and tell menunjukkan bahwa siswa telah menunjukkan peningkatan keterampilan mereka dalam berbicara. Hasil dari tindakan yang dilakukan tersebut sesuai dengan pendapat Tadkiroatun (Musfiroh, 2005) yang menyatakan bahwa manfaat metode show and tell salah satunya adalah untuk meningkatkan keterampilan berbicara siswa. Pendapat tersebut dipertegas oleh Euis (Rohaeti, 2011) yang menyatakan bahwa show and tell mampu mengembangkan keterampilan berbicara atau oral language skills dan sangat efektif untuk mengenalkan kemampuan public speaking karena berkenaan dengan kemampuan berbicara dengan susunan kalimat yang lengkap.

Show and tell pada Siklus I menggunakan media gambar yang disesuaikan dengan tema dan subtema pada setiap pertemuan. Gambar berfungsi untuk membuat pesan verbal yang disampaikan siswa menjadi konkret. Menurut Tadkiroatun Musfiroh (2011: 34), gambar dan foto relatif efektif untuk menstimulasi kemampuan bertata krama, tanggung jawab, dan kemandirian. Selain gambar, siswa juga Show and tell menggunakan hasil karya mereka. Hal ini sejalan dengan pendapat Hoerr (2007: 94-95) yang menyatakan bahwa siswa dapat Show and Tell menggunakan hasil karya atau proyek yang telah dibuat. Dari aspek kebahasaan siswa meningkat dari siklus I sampai siklus II seperti pengucapan, pengembangan kosa kata, dan pembentukan kalimat. Dari aspek non kebahasaan yaitu siswa sudah menunjukkan keberanian yang baik untuk melakukan show and tell dengan lancar dan ekspresi mulai berkembang. Dhieni (Nurbiana, 2005) menyatakan bahwa siswa memahami apa yang diceritakan melalui penghayatan saat berbicara. Melalui penghayatan yang baik akan muncul ekspresi suara, ekspresi muka, bahkan gerak tubuh yang mendukung cerita. Pada akhir Siklus II, ekspresi atau gerak-gerik tubuh siswa meningkat ditunjukkan dari sebagian besar siswa dapat berekspresi muka dan suara sesuai dengan topik yang dibicarakan disertai gerak tubuh.

\section{Simpulan}

Berdasarkan hasil pembahasan penelitian dapat disimpulkan bahwa keterampilan berbicara siswa kelas IV SD Negeri 1 Pernasidi dapat ditingkatkan melalui metode show and tell. Berdasarkan hasil data observasi pada aspek pengucapan, pengembangan kosakata, pembentukan kalimat, keberanian, kelancaran, dan ekspresi atau gerak-gerik tubuh yang telah diperoleh, keterampilan berbicara setiap siklus mengalami peningkatan. 
Guru diharapkan dapat meningkatkan keterampilan berbicara siswa melalui penerapan metode show and tell dengan pengelolaan waktu yang baik dan memperhatikan kondisi kelas. Bagi sekolah diharapkan sekolah memiliki kerjasama yang baik dalam melaporkan perkembangan kemampuan siswa kepada orangtua khususnya keterampilan berbicara siswa, supaya terjadi keselarasan dalam menstimulasi perkembangan siswa ketika di sekolah maupun di rumah.

\section{Daftar Pustaka}

Dailey (1997) 'Journal., Sharing centers: an alternative approach to show and tell. Early childhood education', 24(4).

Marisa, S. (2019) 'Pengaruh Motivasi dalam Pembelajaran Siswa Upaya Mengatasi Permaslahan Belajar', Jurnal Taushiah, 9(2), pp. 20-27. Available at: https://jurnal.uisu.ac.id/index.php/tsh/article/view/1786.

Musfiroh (2005) Bermain sambil Belajar dan Mengasah Kecerdasan (Simulasi Multiple Intelligences Anak Usia Taman Kanakkanak). Jakarta: Departemen Pendidikan Nasional.

Nidawati (2013) 'BELAJAR DALAM PERSPEKTIF PSIKOLOGI DAN AGAMA', Journal of Chemical Information and Modeling, 53(9), pp. 1689-1699.

Nurbiana (2005) Metode Pengembangan Bahasa. Jakarta: Universitas Terbuka.

Rohaeti (2011) Upaya Guru dalam Meningkatkan Keterampilan Berbicara Siswa melalui Metode Show and Tell pada Pembelajaran Bahasa dan Sastra Indonesia di Kelas 2 SDN 3 Cikahuripan Lembang. Skripsi. Bandung, Universitas Pendidikan Indonesia. Universitas Pendidikan Indonesia.

Syamsiara Nur, S. P. (2017) 'Efektivitas Model Problem Based Learning (Pbl) terhadap Hasil Belajar Mahasiswa Prodi Pendidikan Biologi Universitas Sulawesi Barat', 2(2), pp. 133-141. doi: 10.31219/osf.io/378f2. 